\title{
Improvements in growth performance, bone mineral status and nutrient digestibility in pigs following the dietary inclusion of phytase are accompanied by modifications in intestinal nutrient transporter gene expression
}

\author{
Stafford Vigors ${ }^{1}$, Torres Sweeney ${ }^{2}$, Cormac J. O'Shea ${ }^{1}$, John A. Browne ${ }^{2}$ and John V. O’Doherty ${ }^{1 *}$ \\ ${ }^{1}$ School of Agriculture and Food Science, University College Dublin, Belfield, Dublin 4, Republic of Ireland \\ ${ }^{2}$ School of Veterinary Medicine, University College Dublin, Belfield, Dublin 4, Republic of Ireland \\ (Submitted 17 December 2013 - Final revision received 21 May 2014 - Accepted 23 May 2014 - First published online 7 July 2014)
}

\section{Abstract}

Phytase (PHY) improves growth performance, nutrient digestibility and bone structure in pigs; however, little is known about its effects on intestinal nutrient transporter gene expression. In the present study, a $44 \mathrm{~d}$ experiment was carried out using forty-eight pigs (11.76 (SEM 0.75$) \mathrm{kg}$ ) assigned to one of three dietary treatment groups to measure growth performance, coefficient of apparent ileal digestibility (CAID), coefficient of apparent total tract nutrient digestibility (CATTD) and intestinal nutrient transporter gene expression. Dietary treatments during the experimental period were as follows: (1) a high-P (HP) diet containing $3.4 \mathrm{~g} / \mathrm{kg}$ available P and $7 \cdot 0 \mathrm{~g} / \mathrm{kg} \mathrm{Ca}$; (2) a low-P (LP) diet containing $1.9 \mathrm{~g} / \mathrm{kg}$ available P and $5.9 \mathrm{~g} / \mathrm{kg} \mathrm{Ca}$; (3) a PHY diet containing LP diet ingredients +1000 phytase units (FTU)/kg of PHY. The PHY diet increased the average daily gain $(P<0.05)$ and final body weight $(P<0.01)$ and decreased the feed conversion ratio $(P<0.05)$ compared with the LP diet. Pigs fed the PHY diet had a higher CAID of gross energy compared with those fed the HP and LP diets $(P<0 \cdot 001)$. Pigs fed the PHY diet had increased CAID of $\mathrm{P}(P<0.01)$ and CATTD of Ca and P $(P<0 \cdot 001)$ compared with those fed the LP diet. The PHY diet increased the gene expression of the peptide transporter 1 (PEPT1/SLC15A1) $(P<0.05)$ in the ileum compared with the LP diet. The LP diet decreased the gene expression of the sodium-glucose-linked transporter 1 (SGLT1/SLC5A1) and GLUT2/SLC2A2 (P<0.05) and increased the expression of membrane Ca channel (TRPVO) and calbindin compared with the HP diet $(P<0 \cdot 001)$. In conclusion, feeding a diet supplemented with PHY improves growth performance and nutrient digestibility as well as increases the gene expression of the peptide transporter PEPT1.

Key words: Phytase: Phosphorus: Gene expression: Nutrient transporters: Bones: Minerals

$\mathrm{P}$ is poorly utilised by pigs because approximately two-thirds of $\mathrm{P}$ in feedstuffs of plant origin is present as phytate, which is largely unavailable for hydrolysis in the digestive tract ${ }^{(1)}$. The phytate molecule is also capable of binding to other nutrients including starch and proteins, thus preventing their absorption $^{(2)}$. The enzyme phytase (PHY) has been shown to improve $\mathrm{P}$ availability and subsequently improve growth, feed efficiency, nutrient utilisation and bone mineralisation to levels comparable to those induced by a diet supplemented with inorganic P, but to reduce nutrient excretion levels ${ }^{(3)}$.

Studies have shown that the dietary inclusion of PHY has an effect on the availability of a number of nutrients ${ }^{(4)}$. The inclusion of PHY improves the digestibility of amino acids, starch, $\mathrm{Ca}$, gross energy (GE), Fe, fat and $\mathrm{Zn}^{(5-9)}$. The action of PHY is likely to increase the availability of free nutrients including amino acids, peptides, fatty acids, glucose, galactose and fructose in the digesta as the phytate molecule undergoes hydrolysis and the bound starch, protein and fat are released. Although it is apparent that nutrient digestibility improves with the dietary inclusion of exogenous PHY, the physiological response of intestinal nutrient transporters to PHY is not well characterised.

Intestinal enterocytes are constantly exposed to fluctuations in dietary nutrients and therefore have to respond to fluctuations in luminal nutrients ${ }^{(10)}$. Fluctuations in nutrient availability may affect the gene expression of nutrient transporters through a mechanism of nutrient sensing ${ }^{(11)}$. Nutrient transporters, expressed on the apical membrane of intestinal

Abbreviations: CAID, coefficient of apparent ileal digestibility; CATTD, coefficient of apparent total tract digestibility; FABP2, fatty acid-binding protein 2; GE, gross energy; HP, high-phosphorus; LP, low-phosphorus; PEPT1, peptide transporter 1; PHY, phytase; PMCA1, plasma membrane Ca ${ }^{2+}$ ATPase; SGLT1, sodium-glucose-linked transporter 1 .

*Corresponding author: J. V. O’Doherty, email john.vodoherty@ucd.ie 
absorptive cells, are directly exposed to an environment that changes significantly with diet, and consequently their expression is adaptively regulated by dietary substrates ${ }^{(12)}$.

The hypothesis that improvements in growth performance, skeletal bone mineralisation and nutrient digestibility following supplementation of a low-P (LP) diet with PHY are accompanied by changes in the gene expression of intestinal nutrient transporters involved in peptide, mineral, carbohydrate and fatty acid transport was tested in the present study.

\section{Materials and methods}

All procedures used in the present experiment were conducted under experimental licence from the Irish Department of Health in accordance with the Cruelty to Animals Act 1876 and the European Communities (Amendment of the Cruelty to Animals Act 1876) Regulations, 1994.

\section{Experimental design and diets}

An experiment with a completely randomised design was carried out to investigate the effects of three dietary treatments on growth performance, coefficient of apparent ileal digestibility (CAID), coefficient of apparent total tract digestibility (CATTD), bone mineral accretion and intestinal nutrient transporter gene expression in growing pigs ( $43 \mathrm{~kg}$ body weight).
The experimental period was divided into two components delineated by a diet change to match the requirements of pigs as they progressed from a phase when fed a nutritionally rich diet after weaning (days $0-23$ ) to a phase when fed a lower-specification diet (days 23-44) ${ }^{(13)}$. The composition and chemical analysis of the experimental diets are summarised in Table 1. Dietary treatments during period 1 (days 0-23) were as follows: (1) a high-P (HP) diet containing $5.9 \mathrm{~g} / \mathrm{kg}$ total $\mathrm{P}, 3.4 \mathrm{~g} / \mathrm{kg}$ available $\mathrm{P}$ and $7 \mathrm{~g} / \mathrm{kg} \mathrm{Ca}$; (2) a LP diet containing $4.9 \mathrm{~g} / \mathrm{kg}$ total $\mathrm{P}, 1.9 \mathrm{~g} / \mathrm{kg}$ available $\mathrm{P}$ and $5.8 \mathrm{~g} / \mathrm{kg} \mathrm{Ca}$; (3) a PHY diet containing LP diet ingredients +1020 phytase units (FTU)/kg of PHY (Ronozyme ${ }^{\circledR}$, DSM Nutritional Products Limited). Dietary treatments during period 2 (days 23-44) were as follows: (1) a HP diet containing $5.9 \mathrm{~g} / \mathrm{kg}$ total $\mathrm{P}, 3 \mathrm{~g} / \mathrm{kg}$ available $\mathrm{P}$ and $6.7 \mathrm{~g} / \mathrm{kg} \mathrm{Ca}$; (2) a LP diet containing $4.1 \mathrm{~g} / \mathrm{kg}$ total $\mathrm{P}, 1.7 \mathrm{~g} / \mathrm{kg}$ available $\mathrm{P}$ and $4.7 \mathrm{~g} / \mathrm{kg} \mathrm{Ca}$; (3) a PHY diet containing LP diet ingredients $+1030 \mathrm{FTU} / \mathrm{kg}$ of PHY. The HP diet was designed to match the standards set out by the $\mathrm{NRC}^{(14)}$ for $\mathrm{Ca}$ and $\mathrm{P}$ levels, while the LP diet was designed to contain both $\mathrm{Ca}$ and $\mathrm{P}$ levels 16\% lower than those outlined by the NRC during period 1 and $30 \%$ lower during period $2^{(14)}$. All diets were designed to contain similar levels of standard ileal digestible lysine ( 13.3 and $11.1 \mathrm{~g} / \mathrm{kg}$ during periods 1 and 2 , respectively) and digestible energy ( 14.7 and $14.3 \mathrm{MJ} / \mathrm{kg}$ during periods 1 and 2, respectively). All diets were offered in meal form.

Table 1. Composition and chemical analysis of the experimental diets (as-fed basis; $\mathrm{g} / \mathrm{kg}$ unless otherwise stated)

\begin{tabular}{|c|c|c|c|c|c|c|}
\hline Dietary treatments & $\begin{array}{c}\text { HP } \\
\text { (days 0-23) }\end{array}$ & $\begin{array}{c}\text { LP } \\
\text { (days 0-23) }\end{array}$ & $\begin{array}{c}\text { PHY } \\
\text { (days 0-23) }\end{array}$ & $\begin{array}{c}\mathrm{HP} \\
\text { (days 23-45) }\end{array}$ & $\begin{array}{c}\text { LP } \\
\text { (days 23-45) }\end{array}$ & $\begin{array}{c}\text { PHY } \\
\text { (days 23-45) }\end{array}$ \\
\hline \multicolumn{7}{|l|}{ Ingredients } \\
\hline Wheat & $400 \cdot 0$ & $400 \cdot 0$ & $400 \cdot 0$ & $404 \cdot 0$ & $406 \cdot 0$ & $406 \cdot 0$ \\
\hline Barley & $194 \cdot 0$ & 203.5 & $203 \cdot 5$ & 307.5 & $318 \cdot 5$ & 318.5 \\
\hline Soyabean meal & $180 \cdot 0$ & $180 \cdot 0$ & $180 \cdot 0$ & $210 \cdot 0$ & $210 \cdot 0$ & $210 \cdot 0$ \\
\hline Full-fat soya & $150 \cdot 0$ & $150 \cdot 0$ & $150 \cdot 0$ & 0 & 0 & 0 \\
\hline Soya oil & $45 \cdot 0$ & $40 \cdot 0$ & $40 \cdot 0$ & $45 \cdot 0$ & $40 \cdot 0$ & $40 \cdot 0$ \\
\hline Limestone & 4.5 & $6 \cdot 0$ & $6 \cdot 0$ & $6 \cdot 0$ & $8 \cdot 0$ & $8 \cdot 0$ \\
\hline Salt & $3 \cdot 0$ & $3 \cdot 0$ & 3.0 & 3.0 & $3 \cdot 0$ & 3.0 \\
\hline Dicalcium phosphate & $11 \cdot 2$ & $5 \cdot 0$ & $5 \cdot 0$ & $12 \cdot 0$ & $2 \cdot 0$ & $2 \cdot 0$ \\
\hline Vitamin and mineral premix* & $3 \cdot 0$ & $3 \cdot 0$ & $3 \cdot 0$ & 3.0 & $3 \cdot 0$ & $3 \cdot 0$ \\
\hline Lys $\mathrm{HCl}$ & $5 \cdot 0$ & $5 \cdot 0$ & $5 \cdot 0$ & $5 \cdot 0$ & $5 \cdot 0$ & $5 \cdot 0$ \\
\hline L-Thr & $2 \cdot 3$ & $2 \cdot 3$ & $2 \cdot 3$ & $2 \cdot 3$ & $2 \cdot 3$ & $2 \cdot 3$ \\
\hline DL-Met & $2 \cdot 2$ & $2 \cdot 2$ & $2 \cdot 2$ & $2 \cdot 2$ & $2 \cdot 2$ & $2 \cdot 2$ \\
\hline Celite & 0.3 & 0.3 & 0.3 & 0.3 & 0.3 & 0.3 \\
\hline \multicolumn{7}{|l|}{ Analysis } \\
\hline DM & 882.9 & 882.9 & 882.9 & $890 \cdot 1$ & $888 \cdot 1$ & $888 \cdot 1$ \\
\hline Crude protein $(\mathrm{N} \times 6.25)$ & $202 \cdot 3$ & $199 \cdot 9$ & $199 \cdot 9$ & $173 \cdot 8$ & $185 \cdot 8$ & $185 \cdot 8$ \\
\hline Neutral-detergent fibre & $144 \cdot 3$ & $103 \cdot 7$ & $103 \cdot 7$ & $128 \cdot 6$ & $126 \cdot 3$ & $126 \cdot 3$ \\
\hline Ash & $45 \cdot 8$ & $43 \cdot 9$ & $43 \cdot 9$ & $44 \cdot 4$ & $37 \cdot 3$ & $37 \cdot 3$ \\
\hline Gross energy (MJ/kg) & $17 \cdot 0$ & $17 \cdot 0$ & $17 \cdot 0$ & $16 \cdot 9$ & $16 \cdot 8$ & $16 \cdot 8$ \\
\hline Digestible energy (MJ/kg) & $14 \cdot 7$ & $14 \cdot 8$ & $14 \cdot 7$ & $14 \cdot 3$ & $14 \cdot 3$ & $14 \cdot 3$ \\
\hline Lys & $13 \cdot 2$ & $13 \cdot 3$ & $13 \cdot 3$ & $11 \cdot 1$ & $11 \cdot 1$ & $11 \cdot 1$ \\
\hline Met and Cys† & $7 \cdot 1$ & $7 \cdot 2$ & $7 \cdot 2$ & $7 \cdot 1$ & 7 & 7 \\
\hline Thr† & $8 \cdot 6$ & $8 \cdot 6$ & $8 \cdot 6$ & $7 \cdot 2$ & $7 \cdot 2$ & $7 \cdot 2$ \\
\hline Trp† & $2 \cdot 4$ & $2 \cdot 4$ & $2 \cdot 4$ & $2 \cdot 0$ & $2 \cdot 0$ & $2 \cdot 0$ \\
\hline $\mathrm{Ca}(\mathrm{g} / \mathrm{kg})$ & $7 \cdot 0$ & 5.9 & 5.9 & $6 \cdot 7$ & $4 \cdot 7$ & $4 \cdot 7$ \\
\hline$P(g / k g)$ & $5 \cdot 9$ & 4.9 & $4 \cdot 9$ & 5.9 & $4 \cdot 1$ & $4 \cdot 1$ \\
\hline Available P $(\mathrm{g} / \mathrm{kg}) \dagger$ & 3.4 & 1.9 & 1.9 & 3.0 & $1 \cdot 7$ & $1 \cdot 7$ \\
\hline Phytase activity (FTU/kg) & 0 & 0 & 1020 & 0 & 0 & 1030 \\
\hline
\end{tabular}

HP, high P; LP, low P; PHY, phytase; FTU, phytase units.

*The premix provided vitamins and minerals (per kg diet) as follows: Cu 25; Zn 100; Se 0.3; Mn 25; I 0.2; retinol 0.3; cholecalciferol 0.05; $\alpha$-tocopherol 40. † Calculated for the tabulated nutritional composition ${ }^{(48)}$. 


\section{Experimental protocol}

A total of forty-eight pigs (Meatline boars $\times$ (Large White $\times$ Landrace) sows) with an average initial body weight of 11.76 (SD 0.75) kg were used in a $44 \mathrm{~d}$ weaner performance study. Pigs were penned in mixed-sex groups of two (eight replicates per treatment) on fully slatted floors $(1.68 \mathrm{~m} \times 1.22 \mathrm{~m})$. Feed and water were available ad libitum with precaution taken to avoid feed wastage. Feed was kept in the feeders until the time the pigs were weighed, and then the feed was weighed again to calculate the feed conversion ratio. Pigs were weighed weekly. The ambient environmental temperature within the houses was thermostatically controlled. The temperature was set at $28^{\circ} \mathrm{C}$ during the 1 st week and was reduced by $2^{\circ} \mathrm{C}$ per week to $22^{\circ} \mathrm{C}$. Multiple fresh faecal samples were collected daily from all pens on days 10-15 during period 1 and on days 25-30 during period 2 and stored in sterile containers (Sarstedt). During the experiment, feed samples were collected at the time of feeding and stored until chemical analysis. Celite $(300 \mathrm{mg} / \mathrm{kg}$ ) was added to the feed during manufacture to measure the CAID and CATTD using the acid-insoluble ash technique ${ }^{(15)}$. On day 44, the male pig from each pen was slaughtered. Pigs were killed by lethal injection of Euthatal (pentobarbitone sodium BP; Merial Animal Limited) at a rate of $1 \mathrm{ml} / 1.4 \mathrm{~kg}$ body weight. After slaughter, the right front foot of twenty-four pigs was cleaned of all skin, muscle and connective tissue to remove the third and fourth metacarpals. Following removal, the metacarpals were again cleaned of any remaining flesh. These bones were subsequently used for the assessment of bone ash, P, and Ca levels and bone density. All metacarpals collected were individually stored at $-20^{\circ} \mathrm{C}$ to prevent desiccation until analysis.

Following a $3 \mathrm{~h}$ fast and slaughter, the entire digestive tract was removed by blunt dissection. Following tract removal, digesta samples were recovered aseptically from the ileum as sections of approximately $30 \mathrm{~cm}$ in length from the ileocaecal valve to measure the CAID of nutrients (N, DM and GE). Tissue samples from the jejunum $(60 \mathrm{~cm}$ from the stomach) and ileum ( $8 \mathrm{~cm}$ from the ileocaecal valve) were collected and emptied by dissecting along the mesentery and rinsing using sterile PBS (Oxoid) as described previously ${ }^{(16,17)}$. Sections measuring $1 \mathrm{~cm}^{2}$, which had been stripped of the overlying smooth muscle, were cut from the tissue samples and stored in RNAlater solution (Applied Biosystems) overnight at $4^{\circ} \mathrm{C}$. RNAlater was removed later, and tissue samples were stored at $-70^{\circ} \mathrm{C}$ until RNA extraction.

\section{Laboratory analysis of samples}

Feed and faecal samples were analysed for N, DM, organic matter, ash, GE and neutral-detergent fibre. Following collection, faecal samples were dried at $100^{\circ} \mathrm{C}$ for $48 \mathrm{~h}$. Feed and dried faecal samples were milled through a $1 \mathrm{~mm}$ screen (Christy and Norris Hammer Mill). Diet, faecal and digesta samples were analysed for DM (method 934.01) and crude ash (method 942.05) according to the $\mathrm{AOAC}^{(18)}$. The $\mathrm{DM}$ content was determined after drying for $24 \mathrm{~h}$ at $100^{\circ} \mathrm{C}$.
The crude ash content was determined after ignition of a weighed sample in a muffle furnace (Nabertherm) at $550^{\circ} \mathrm{C}$ for $6 \mathrm{~h}$. The ash was then digested in aqua regia $\left(\mathrm{HCl}-\mathrm{HNO}_{3}\right.$ mixture). In the first round of digestion, ash was digested using 20\% aqua regia (4:1 $\mathrm{HCl}$ and nitric acid (v/v)) and subsequently digested using $25 \%$ aqua regia. This solution was used for the determination of $\mathrm{P}$ and $\mathrm{Ca}$ concentrations. The concentration of $\mathrm{Ca}$ in feed, digesta and faecal samples was determined using an atomic absorption spectrophotometer (Varian 50; Varian, Inc.) using the method of Ramakrishna \& Robinson $^{(19)}$. The concentration of $\mathrm{P}$ was determined spectrophotometrically (PU 8600 UV/visible spectrophotometer, Pye Unicam, Philips) using the method of Cavell ${ }^{(20)}$. The GE was determined using an adiabatic bomb calorimeter (Parr Instruments) as described by O'Shea et al. ${ }^{(21)}$. The neutral-detergent fibre fraction was analysed using the Fibertec Extraction Unit (Fibertec, Tecator) as described by Van Soest et al. ${ }^{(22)}$. The concentration of $\mathrm{N}$ in diet, faecal and digesta samples was determined using a LECO FP 528 (Leco Instruments (U.K.) Limited) as described by O'Shea et ll $^{(21)}$. The concentration of acid-insoluble ash was determined according to the method of McCarthy et al. ${ }^{(23)}$. Feed samples were analysed for PHY activity according to the method reported by Brady et $a l^{(24)}$. PHY activity is expressed as FTU per unit of feed and is defined as the quantity of enzyme that liberates $1 \mu \mathrm{mol}$ of inorganic P per min from a $1.5 \mathrm{mmol} / 1$ solution of sodium phytate at $\mathrm{pH} 5.5$ and $37^{\circ} \mathrm{C}^{(25)}$.

\section{Bone analysis}

Bone samples were analysed for DM, density, ash, Ca and P. Bone density was calculated using a balance (Scout Pro balance $200 \mathrm{~g} \times 0.01 \mathrm{~g}$, Ohaus Limited). The samples were first weighed in air and then weighed by submerging in distilled water using the integral weigh-below hook facility. Bone volume was calculated by subtracting the wet weight from the dry weight, and bone density was determined by dividing the dry weight by the volume ${ }^{(26)}$. The samples were placed in an oven at $100^{\circ} \mathrm{C}$ for $16 \mathrm{~h}$ to determine $\mathrm{DM}$ weight. The samples were then ashed at $650^{\circ} \mathrm{C}$ in a muffle furnace, and the ash was digested in aqua regia $\left(\mathrm{HCl}-\mathrm{HNO}_{3}\right.$ mixture) and analysed for $\mathrm{Ca}$ and $\mathrm{P}$ as described above for faecal and digesta samples.

\section{RNA extraction and real-time RT-PCR}

Total RNA was extracted from ileal and jejunal samples ( $25 \mathrm{mg}$ ) using TRIzol Reagent (Sigma-Aldrich) according to the manufacturer's instructions. The crude RNA extract was further purified using the GenElute Mammalian Total RNA Miniprep Kit (RTN70, Sigma-Aldrich) according to the manufacturer's instructions. A DNase removal step was included (DNASE7-E70, Sigma-Aldrich). The total RNA was quantified using a NanoDrop-ND1000 spectrophotometer (Thermo Fisher Scientific, Inc.). The purity of RNA was assessed by determining the ratio of the absorbance at $260 \mathrm{~nm}$ to that at $280 \mathrm{~nm}$. All total RNA samples had 260:280 $\mathrm{nm}$ ratios above 1.8. In addition, the integrity of RNA was verified using the Agilent RNA 6000 NanoChip Bioanalyzer Kit (Agilent Technologies). All samples 
had a RNA integrity number above 8 (average 8.3 (SE 0.59)). Total RNA $(1 \mu \mathrm{g})$ was reverse-transcribed using a commercially available complementary DNA synthesis kit (First Strand cDNA Synthesis Kit, Fermentas) using oligo-deoxy-thymine (dT) primers in a final reaction volume of $20 \mu \mathrm{l}$ according to the manufacturer's instructions, and minus-RT and no-template controls were included. The final reverse transcription product was adjusted to a volume of $120 \mu \mathrm{l}$ using nuclease-free water. The mRNA expression profiles of selected candidate genes were analysed by quantitative real-time PCR using the ABI Prism 7500 FAST Sequence Detection System (Applied Biosystems). PCR amplification was performed in a total volume of $20 \mu \mathrm{l}$ containing $10 \mu \mathrm{l}$ of master mix (SYBR PCR Master Mix, Applied Biosystems), $1 \cdot 0 \mu \mathrm{l}$ of forward and reverse primers $(300 \mathrm{pm}$ final), $6.5 \mu \mathrm{l}$ of RNAse-free water, and $2.5 \mu \mathrm{l}$ of template complementary DNA ( $5.0 \mathrm{ng}$ of RNA equivalents). The two-step PCR programme was as follows: $95^{\circ} \mathrm{C}$ for $10 \mathrm{~min}$ for one cycle, followed by $95^{\circ} \mathrm{C}$ for $15 \mathrm{~s}$ and $60^{\circ} \mathrm{C}$ for $1 \mathrm{~min}$ for forty cycles. All reactions were performed in duplicate. Primers were designed for each gene of interest (Primer Express Software version 2.0, Applied Biosystems), and the specificity of all primers was confirmed by melting curve analysis. Primer efficiency was determined using a serial dilution of Sus scrofa-derived complementary DNA (1:4 dilution series over seven points). Primers for all the selected nutrient transporters (peptide transporter 1 (PEPT1/SLC15A1); sodium-glucose-linked transporter 1 (SGLT1/SLC5A1); GLUT2/SLC2A2, GLUT5/SLC2A5, GLUT7/ $S L C 2 A 7$, and GLUT8/SLC2A8; fatty acid-binding protein 2 (FABP2); Fe-regulated transporter (SLC4OA1); cluster of differentiation 36/fatty acid translocase (CD36/FAT); membrane Ca channel (TRPVO); Ca-binding protein (calbindin); plasma membrane $\mathrm{Ca}^{2+}$ ATPase (PMCA1) and vitamin D receptor $\left.(V D R)\right)$ are given in Table 2. The optimal number of reference targets for this sample set was identified using the geNorm application within the qbasePLUS software package ${ }^{(27)}$ (Biogazelle) and confirmed for the present study (geNorm $V<0 \cdot 15$ ). The normalisation factor

Table 2. Porcine specific primers used for real-time PCR

\begin{tabular}{|c|c|c|c|c|c|}
\hline Genes & Accession no. & Primer sequence $\left(5^{\prime}-3^{\prime}\right)$ & Melting temperature $\left({ }^{\circ} \mathrm{C}\right)$ & Product length (bp) & Efficiency (\%) \\
\hline GAPDH & AF017079.1 & F: CAGCAATGCCTCCTGTACCA & $59 \cdot 4$ & 72 & 100 \\
\hline HMBS & NM_001097412.1 & $\begin{array}{l}\text { R: ACGATGCCGAAGTTGTCATG } \\
\text { F: CTGAACAAAGGTGCCAAGAACA } \\
\text { R: GCCCCGCAGACCAGTTAGT }\end{array}$ & $\begin{array}{l}57 \cdot 3 \\
58 \cdot 4 \\
61\end{array}$ & 74 & 104 \\
\hline PEPT1 & NM_214347.1 & $\begin{array}{l}\text { F: GGATAGCCTGTACCCCAAGCT } \\
\text { R: CATCCTCCACGTGCTTCTTGA }\end{array}$ & $\begin{array}{l}61 \cdot 8 \\
59 \cdot 8\end{array}$ & 73 & 98 \\
\hline SGLT1 & NM_001164021.1 & $\begin{array}{l}\text { F: GGCTGGACGAAGTATGGTGT } \\
\text { R: ACAACCACCCAAATCAGAGC }\end{array}$ & $\begin{array}{l}59 \cdot 4 \\
57 \cdot 3\end{array}$ & 153 & 90 \\
\hline GLUT2 & AF054835.1 & $\begin{array}{l}\text { F: CCAGGCCCCATCCCCTGGTT } \\
\text { R: GCGGGTCCAGTTGCTGAATGC }\end{array}$ & $\begin{array}{l}65 \cdot 5 \\
63 \cdot 7\end{array}$ & 96 & 101 \\
\hline GLUT5 & EU_012359 & $\begin{array}{l}\text { F: CCCAGGAGCCGGTCAAG } \\
\text { R: TCAGCGTCGCCAAAGCA }\end{array}$ & $\begin{array}{l}60 \\
55 \cdot 2\end{array}$ & 60 & 107 \\
\hline GLUT7 & XM_003127552.3 & $\begin{array}{l}\text { F: ACATCGCCGGACATTCCATA } \\
\text { R: GCGAGGACTGCAGGAAGATC }\end{array}$ & $\begin{array}{l}57 \cdot 3 \\
61 \cdot 4\end{array}$ & 75 & 110 \\
\hline GLUT8 & XM_003480608.1 & $\begin{array}{l}\text { F: AGCGCCTTTGGCACCTACTT } \\
\text { R: TGCACGTGCGAGGAGTTG }\end{array}$ & $\begin{array}{l}59 \cdot 4 \\
58 \cdot 2\end{array}$ & 62 & 110 \\
\hline$F A B P 2$ & NM_001031780.1 & $\begin{array}{l}\text { F: TCGGGATGAAATGGTCCAGACT } \\
\text { R: TGTGTTCTGGGCTGTGCTCCA }\end{array}$ & $\begin{array}{l}62 \cdot 4 \\
61 \cdot 8\end{array}$ & 102 & 106 \\
\hline$C D 36$ & NM_001044622.1 & $\begin{array}{l}\text { F: GGAGAAAAGATCACTACCATCATGAG } \\
\text { R: CTCCTGAAGTGCAATGTACTGACA }\end{array}$ & $\begin{array}{l}61 \cdot 6 \\
61\end{array}$ & 78 & 98 \\
\hline$V D R$ & NM_001097414.1 & $\begin{array}{l}\text { F: CCTTCACCATGGACGACATG } \\
\text { R: TGGCCACGTCGCTGACTT }\end{array}$ & $\begin{array}{l}59 \cdot 4 \\
58 \cdot 2\end{array}$ & 72 & 92 \\
\hline TRPV6 & XM_003134594 & $\begin{array}{l}\text { F: TCCAGACAGAGGACCCTAACAAG } \\
\text { R: GTGAGAAACAGCTCAAAGGTGCTA }\end{array}$ & $\begin{array}{l}62 \cdot 4 \\
61\end{array}$ & 82 & 104 \\
\hline Calbindin & NM_214140.2 & $\begin{array}{l}\text { F: CGCAACAGTCCCATTTAAGGA } \\
\text { R: TCAGCAGAGACATGGGTGGTT }\end{array}$ & $\begin{array}{l}57 \cdot 9 \\
59 \cdot 8\end{array}$ & 72 & 90 \\
\hline PMCA1 & NM_214352.3 & $\begin{array}{l}\text { F: GGGCGGGCAGGTCATT } \\
\text { R: CCGCCGGGAGAAGATCA }\end{array}$ & $\begin{array}{l}56 \cdot 9 \\
57 \cdot 6\end{array}$ & 86 & 94 \\
\hline SLC4OA1 & XM_003483701 & $\begin{array}{l}\text { F: GGAGCATCAGCTGTAACTGGAA } \\
\text { R: CCGAACCAGGCCACATTTT }\end{array}$ & $\begin{array}{l}60 \cdot 3 \\
56 \cdot 7\end{array}$ & 75 & 109 \\
\hline SLC1A4 & XM_003125088 & $\begin{array}{l}\text { F: ACCCTCGCCGACTTTTAGTCT } \\
\text { R: GCCTGTGCCGAGAAGTAATCC }\end{array}$ & $\begin{array}{l}59 \cdot 8 \\
61 \cdot 8\end{array}$ & 76 & 99 \\
\hline SLC6A19 & XM_003359855 & $\begin{array}{l}\text { F: GCCACCGTGGTCTACTCCAT } \\
\text { R: GAAGTTCTCCTGCGTCACGTT }\end{array}$ & $\begin{array}{l}61.4 \\
59 \cdot 8\end{array}$ & 129 & 95 \\
\hline SLC7A11 & XM_003360551 & $\begin{array}{l}\text { F: CGGCTCCTGGGAAATTTCTC } \\
\text { R: ACCATTCATGGAGCCAAAGC }\end{array}$ & $\begin{array}{l}59 \cdot 4 \\
57 \cdot 3\end{array}$ & 72 & 95 \\
\hline$S L C 7 A 1$ & NM_001012613 & $\begin{array}{l}\text { F: TCTCATCCTAACGGGACTTTTAACTC } \\
\text { R: GACCAGAACGTTGATACACGTGAA }\end{array}$ & $\begin{array}{l}61 \cdot 6 \\
61\end{array}$ & 85 & 110 \\
\hline SLC34A2 & XM_003128893 & $\begin{array}{l}\text { F: GAAAGGCACAGAGACCCACAA } \\
\text { R: AATGGGACGGCTGGAGTTC }\end{array}$ & $\begin{array}{l}59 \cdot 8 \\
58 \cdot 8\end{array}$ & 71 & 95 \\
\hline SLC17A4 & XM_001925551 & $\begin{array}{l}\text { F: TTTTCAATTTCCACCCAACAAAT } \\
\text { R: GGGTGGGCAGAGCTGTGT }\end{array}$ & $\begin{array}{l}58 \cdot 2 \\
56 \cdot 0\end{array}$ & 76 & 105 \\
\hline
\end{tabular}

$G A P D H$, glyceraldehyde 3-phosphate dehydrogenase; HMBS, hydroxymethylbilane synthase; $P E P T$, peptide transporter; SGLT, sodium-glucose-linked transporter; $F A B P$, fatty acid-binding protein; $C D$, cluster of differentiation; VDR, vitamin D receptor; TRPV6, membrane Ca channel; PMCA1, plasma membrane Ca ${ }^{2+} \mathrm{ATPase}$; $S L C$, solute carrier. 
was calculated as the geometric mean of the reference targets glyceraldehyde 3-phosphate dehydrogenase (GAPDH) and hydroxymethylbilane synthase (HMBS). Calibrated normalised relative quantities of gene expression for each analysed sample were generated using the qbasePLUS package (Biogazelle) and incorporated efficiency correction.

\section{Statistical analysis}

Data were analysed as a completely randomised block design using the general linear model procedure of SAS (SAS Institute, Inc.) ${ }^{(28)}$. The pen served as the experimental unit for performance and CATTD. For all the other parameters, the individual pig served as the experimental unit. Data were checked for normality using the PROC UNIVARIATE function of SAS (SAS Institute, Inc.). All data presented in the tables are expressed as least-squares means with their standard errors. Means were separated using the Tukey-Kramer method. $P$ values $<0.05$ were considered to be statistically significant.

\section{Results}

\section{Growth performance}

The effect of PHY and P levels on the growth performance of pigs is summarised in Table 3. At the end of the experiment, pigs fed the LP diet had lower overall average daily gain $(P<0.05)$ and final body weight $(P<0.01)$ and an increased feed conversion ratio $(P<0.05)$ compared with those fed the $\mathrm{HP}$ and PHY diets.

\section{Apparent ileal digestibility}

The effect of PHY and P levels on the CAID of pigs is summarised in Table 4. Pigs fed the PHY diet had higher CAID of GE

Table 3. Effect of phosphorus and phytase (PHY) levels on the growth performance of pigs during period 1 (days $0-23$ ) and period 2 (days 23-44)

(Least-squares means with their standard errors)

\begin{tabular}{lrrrrr}
\hline Dietary treatments & HP & LP & PHY & SEM & $P$ \\
\hline Period 1(days 0-23) & & & & & \\
Initial BW (kg) & 11.76 & 11.76 & 11.75 & 0.75 & 0.894 \\
Final BW (kg) & 25.81 & 25.13 & 26.73 & 0.27 & 0.505 \\
ADFI (kg/d) & 0.89 & 0.93 & 0.91 & 0.03 & 0.594 \\
ADG (kg/d) & 0.61 & 0.58 & 0.65 & 0.02 & 0.495 \\
FCR (kg/kg) & 1.49 & 1.65 & 1.43 & 0.07 & 0.251 \\
Period 2 (days 23-44) & & & & & \\
Final BW (kg) & $41.28^{\mathrm{a}}$ & $37.06^{\mathrm{b}}$ & $43.16^{\mathrm{a}}$ & 1.02 & 0.024 \\
ADFI (kg/d) & 1.47 & 1.49 & 1.51 & 0.08 & 0.594 \\
ADG (kg/d) & $0.74^{\mathrm{a}}$ & $0.57^{\mathrm{b}}$ & $0.78^{\mathrm{a}}$ & 0.02 & 0.001 \\
FCR (kg/kg) & $1.99^{\mathrm{a}}$ & $2.63^{\mathrm{b}}$ & $1.92^{\mathrm{a}}$ & 0.13 & 0.025 \\
Entire period (days 0-44) & & & & & \\
ADFI (kg/d) & 1.16 & 1.19 & 1.19 & 0.04 & 0.805 \\
ADG (kg/d) & $0.67^{\mathrm{a}}$ & $0.58^{\mathrm{b}}$ & $0.71^{\mathrm{a}}$ & 0.02 & 0.026 \\
FCR (kg/kg) & $1.73^{\mathrm{a}}$ & $2.14^{\mathrm{b}}$ & $1.67^{\mathrm{a}}$ & 0.09 & 0.043 \\
\hline
\end{tabular}

HP, high P; LP, low P; BW, body weight; ADFI, average daily feed intake; ADG, average daily gain; FCR, feed conversion ratio.

${ }^{a, b}$ Least-squares mean values within a row with unlike superscript letters were significantly different $(P<0.05)$

${ }^{*} \mathrm{~A}$ total of eight replicates were used per treatment.
$(P<0.001)$ and $\mathrm{N}(P<0.05)$ compared with those fed the HP diet. Pigs fed the PHY diet had higher CAID of $\mathrm{P}$ $(P<0.01)$, ash $(P<0.05)$ and $\mathrm{GE}(P<0.001)$ compared with those fed the LP diet.

\section{Total tract digestibility}

The effect of PHY and P levels on the CATTD of pigs is summarised in Table 4. Pigs fed the PHY diet had higher CATTD of $\mathrm{Ca}, \mathrm{P}$ and ash compared with those fed the HP and LP diets $(P<0.001)$ during periods 1 and 2 . Pigs fed the LP diet had a lower CATTD of $\mathrm{P}$ compared with those fed the HP diet $(P<0 \cdot 001)$ during periods 1 and 2 .

\section{Bone parameters}

The effect of PHY and P levels on the bone parameters of pigs is summarised in Table 5. Pigs fed the LP diet had decreased bone ash content $(P<0.001)$, bone $\mathrm{P}$ content $(P<0.01)$ and bone density $(P<0.01)$ compared with those fed the HP and PHY diets.

\section{Jejunal nutrient transporter gene expression}

The effect of PHY and P levels on the jejunal nutrient transporter gene expression of pigs is summarised in Table 6. Pigs fed the PHY diet exhibited a numerical increase in the gene expression of the Ca transporter TRPVG $(P<0 \cdot 10)$ and the $\mathrm{P}$ transporter $S L C 34 A 2(P<0 \cdot 10)$ compared with those fed the HP diet. Pigs fed the HP diet exhibited an increased gene expression of the amino acid transporter SLC7A11 compared with those fed the PHY diet $(P<0.05)$. Pigs fed the HP diet exhibited a numerical increase in the gene expression of the amino acid transporter $S L C 7 A 1$ compared with those fed the LP diet $(P<0 \cdot 10)$.

\section{Ileal nutrient transporter gene expression}

The effect of PHY and P levels on the ileal nutrient transporter gene expression of pigs is summarised in Table 7. Pigs fed the PHY diet exhibited an increased gene expression of PEPT1 compared with those fed the LP diet $(P<0.05)$. Pigs fed the PHY diet exhibited a numerical increase in the gene expression of FABP2 $(P<0 \cdot 10)$ compared with those fed the LP diet. Pigs fed the LP diet exhibited a lower gene expression of GLUT2 and SGLT1 compared with those fed the HP diet $(P<0.05)$. Pigs fed the LP diet exhibited an increase in the gene expression of the Ca transporters TRPVG, calbindin and PMCA1 compared with those fed the HP and PHY diets $(P<0 \cdot 001)$.

\section{Discussion}

PHY is used extensively to improve $\mathrm{P}$ digestibility in pigs, by increasing the availability of phytate-bound $\mathrm{P}$ and improving growth performance and bone mineralisation. PHY supplementation has also been shown to improve the digestibility of a number of nutrients ${ }^{(4)}$. We hypothesised that improvements 
Table 4. Effect of phosphorus and phytase (PHY) levels on the coefficient of apparent total tract digestibility (CATTD) (periods 1 and 2) and the coefficient of apparent ileal digestibility (CAID) of pigs (after slaughter (day 43))

(Least-squares means with their standard errors)

\begin{tabular}{|c|c|c|c|c|c|}
\hline Dietary treatments* & $\mathrm{HP}$ & LP & $\mathrm{PHY}$ & SEM & $P$ \\
\hline \multicolumn{6}{|l|}{ CAID (\%) } \\
\hline DM & $72 \cdot 06^{\mathrm{a}}$ & $73 \cdot 50^{a, b}$ & $77.06^{\mathrm{b}}$ & 0.52 & 0.001 \\
\hline Ash & $34 \cdot 79^{a, b}$ & $30.67^{a}$ & $43.24^{\mathrm{b}}$ & $4 \cdot 61$ & 0.043 \\
\hline $\mathrm{P}$ & $36 \cdot 69^{a, b}$ & $22 \cdot 37^{\mathrm{a}}$ & $47 \cdot 39^{\mathrm{b}}$ & $5 \cdot 31$ & 0.006 \\
\hline Gross energy & $69.95^{\mathrm{a}}$ & $71 \cdot 47^{\mathrm{a}}$ & $74 \cdot 77^{\mathrm{b}}$ & 0.71 & 0.001 \\
\hline $\mathrm{N}$ & $66 \cdot 95^{\mathrm{a}}$ & $70 \cdot 04^{a, b}$ & $71.58^{b}$ & 1.43 & 0.001 \\
\hline \multicolumn{6}{|l|}{ CATTD (days $0-23$ ) (\%) } \\
\hline DM & 81.35 & $82 \cdot 3$ & $82 \cdot 16$ & 1.43 & 0.292 \\
\hline Ash & $40.59^{a}$ & $42 \cdot 46^{\mathrm{a}}$ & $57.96^{\mathrm{b}}$ & $2 \cdot 13$ & 0.001 \\
\hline $\mathrm{P}$ & $32 \cdot 89^{\mathrm{a}}$ & $21 \cdot 84^{\mathrm{b}}$ & $54.52^{\mathrm{c}}$ & 3.23 & 0.001 \\
\hline $\mathrm{Ca}$ & $46 \cdot 41^{\mathrm{a}}$ & $48 \cdot 13^{\mathrm{a}}$ & $75 \cdot 41^{\mathrm{b}}$ & 3.98 & 0.001 \\
\hline Gross energy & $75 \cdot 72$ & 78.86 & 79.79 & 1.86 & 0.331 \\
\hline $\mathrm{N}$ & $76 \cdot 14$ & 78.54 & $76 \cdot 8$ & 2.05 & 0.335 \\
\hline Neutral-detergent fibre & 13.66 & $12 \cdot 22$ & $17 \cdot 21$ & 2.48 & 0.246 \\
\hline \multicolumn{6}{|l|}{ CATTD (days 23-44) (\%) } \\
\hline DM & 82.68 & 82.66 & 84.44 & 0.82 & 0.258 \\
\hline Ash & $43 \cdot 21^{a}$ & $40 \cdot 37^{a}$ & $58 \cdot 79^{b}$ & 3.41 & 0.002 \\
\hline $\mathrm{P}$ & $38.94^{\mathrm{a}}$ & $22 \cdot 02^{\mathrm{b}}$ & $55 \cdot 8^{\mathrm{c}}$ & 4.31 & 0.001 \\
\hline $\mathrm{Ca}$ & $48 \cdot 77^{\mathrm{a}}$ & $45 \cdot 41^{\mathrm{a}}$ & $76 \cdot 64^{\mathrm{b}}$ & 4.30 & 0.001 \\
\hline Gross energy & 79.74 & 79.53 & $80 \cdot 76$ & 7.06 & 0.662 \\
\hline $\mathrm{N}$ & $78 \cdot 11$ & 79.95 & $80 \cdot 18$ & 1.02 & 0.443 \\
\hline Neutral-detergent fibre & 15.49 & 13.66 & $19 \cdot 18$ & $2 \cdot 62$ & 0.343 \\
\hline
\end{tabular}

in growth performance, skeletal bone mineralisation and nutrient digestibility following supplementation of a LP diet with PHY are accompanied by changes in the gene expression of intestinal nutrient transporters involved in peptide, mineral, carbohydrate and fatty acid transport.

The primary aim of the present study was to investigate the effects of PHY on nutrient and mineral digestibility, growth performance and bone mineralisation and the secondary aim was to investigate its effect on intestinal nutrient transporter gene expression in pigs. The experimental period was divided into two components delineated by a diet change to match the requirements of pigs as they progressed from a phase when fed a nutritionally rich diet after weaning (days 0-23) to a phase when fed a lower-specification diet (days 23-44) ${ }^{(13)}$. In the present study, the PHY diet was found to improve the CATTD of $\mathrm{Ca}$ and $\mathrm{P}$, the CAID of GE and $\mathrm{P}$, growth performance and bone mineralisation and to increase the CAID of $\mathrm{N}$ when compared with the HP diet. The findings of the present study are in agreement with the findings that supplementation of a LP diet with PHY can improve nutrient digestibility, growth performance and bone mineralisation ${ }^{(4,29,30)}$. These improvements have been attributed to the capacity of PHY to release nutrients chelated by the phytate molecule. The PHY diet increased the CAID of GE compared with the LP diet and increased the CAID of $\mathrm{N}$ compared with the HP diet. However, there was no difference in the CATTD of $\mathrm{N}$ and GE among the dietary treatment groups, indicating that activity in the large intestine affects the CATTD of $\mathrm{N}$ and GE. Similarly, Woyengo et al. ${ }^{(31)}$ suggested that hindgut fermentation masks the effects of PHY. This is important, as nutrients absorbed in the small intestine are used with greater efficiency than those that undergo hindgut fermentation. Nutrients such as amino acids that are not absorbed in the small intestine are of no nutritional value to pigs. Although the effects of PHY on growth performance, nutrient digestibility and bone mineralisation ${ }^{(32-34)}$ are well established, the underlying biological mechanisms involved in the uptake of nutrients following the degradation of the phytate molecule are not well understood. Intestinal enterocytes respond to fluctuations in intestinal nutrients by modifying the gene expression of intestinal nutrient transporters ${ }^{(10,11)}$. This indicates that intestinal enterocytes can up-regulate the gene expression of nutrient transporters in response to increased nutrient availability. In previous studies, improvements in nutrient digestibility have been found to be accompanied by improvements in intestinal nutrient transporter

Table 5. Effect of phosphorus and phytase (PHY) levels on bone parameters in the fourth metacarpal of the right front leg of pigs during slaughter (day 43)

(Least-squares means with their standard errors)

\begin{tabular}{lcccrc}
\hline Dietary treatments $^{*}$ & HP & LP & PHY & SEM & $P$ \\
\hline DM & 753.4 & 723.5 & 742.8 & 12.13 & 0.242 \\
Ash & $444.8^{\mathrm{a}}$ & $395 \cdot 1^{\mathrm{b}}$ & $450.4^{\mathrm{a}}$ & 9.45 & 0.001 \\
$\mathrm{P}$ & $53.7^{\mathrm{a}}$ & $46.4^{\mathrm{b}}$ & $54.3^{\mathrm{a}}$ & 0.75 & 0.001 \\
Ca & $116 \cdot 7$ & 114.8 & 117.5 & 3.82 & 0.574 \\
Density $\dagger$ & $1.54^{\mathrm{a}}$ & $1.41^{\mathrm{b}}$ & $1.55^{\mathrm{a}}$ & 0.02 & 0.001 \\
\hline
\end{tabular}

HP, high $\mathrm{P}$; LP, low $\mathrm{P}$.

${ }_{a, b}$ Least-squares mean values within a row with unlike superscript letters were significantly different $(P<0.05)$.

${ }^{*} A$ total of eight replicates were used per treatment.

†Density was calculated according to the method of Giancoli et al. ${ }^{(26)}$ 
Table 6. Effect of phosphorus and phytase (PHY) levels on the normalised relative abundance of nutrient transporter mRNA in the jejunal tissue of weaned pigs

(Least-squares means with their standard errors)

\begin{tabular}{llllll}
\hline Dietary treatments & HP & LP & PHY & SEM & $P$ \\
\hline Glucose & & & & & \\
GLUT2 & 1.28 & 0.93 & 1.17 & 0.23 & 0.596 \\
GLUT5 & 1.04 & 0.94 & 1.16 & 0.13 & 0.473 \\
GLUT7 & 1.36 & 1.26 & 0.83 & 0.25 & 0.317 \\
GLUT8 & 1.29 & 0.88 & 1.19 & 0.24 & 0.477 \\
SGLT1 & 0.85 & 0.98 & 1.30 & 0.19 & 0.256 \\
Protein & & & & & \\
PEPT1 & 1.32 & 1.09 & 1.07 & 0.23 & 0.694 \\
SLC1A4 & 0.98 & 1.12 & 1.11 & 0.19 & 0.839 \\
SLC6A19 & 1.13 & 1.06 & 1.03 & 0.15 & 0.891 \\
SLC7A1 & $1.15^{\mathrm{a}}$ & $0.88^{\mathrm{b}}$ & $1.01^{\mathrm{a}} \mathrm{b}$ & 0.10 & 0.078 \\
SLC7A11 & $1.24^{\mathrm{a}}$ & $1.05^{\mathrm{a}, \mathrm{b}}$ & $0.78^{\mathrm{b}}$ & 0.14 & 0.034 \\
Fatty acids and vitamins & & & & & \\
CD36 & 1.45 & 1.27 & 0.82 & 0.45 & 0.605 \\
FABP2 & 1.49 & 1.12 & 1.04 & 0.26 & 0.426 \\
VDR & 1.20 & 1.13 & 1.19 & 0.30 & 0.985 \\
Minerals & & & & & \\
TRPV6 & $0.82^{\mathrm{a}}$ & $1.13^{\mathrm{a}, \mathrm{b}}$ & $1.18^{\mathrm{b}}$ & 0.14 & 0.086 \\
PMCA1 & 1.18 & 1.00 & 1.09 & 0.18 & 0.801 \\
Calbindin & 1.00 & 1.03 & 1.08 & 0.12 & 0.909 \\
SLC40A1 & 1.18 & 1.17 & 1.28 & 0.32 & 0.968 \\
SLC17A4 & 0.97 & 1.31 & 1.05 & 0.33 & 0.750 \\
SLC34A2 & $0.80^{\mathrm{a}}$ & $0.98^{\mathrm{a}, \mathrm{b}}$ & $1.39^{\mathrm{b}}$ & 0.21 & 0.061 \\
\hline
\end{tabular}

HP, high P; LP, low P; SGLT1, sodium-glucose-linked transporter 1; PEPT1, peptide transporter 1; $C D 36$, cluster of differentiation 36; $F A B P 2$, fatty acid-binding protein 2; VDR, vitamin D receptor; TRPV6, membrane Ca channel; PMCA1, plasma membrane $\mathrm{Ca}^{2+}$ ATPase.

${ }^{a, b}$ Least-squares mean values within a row with unlike superscripts were significantly different $(P<0.05)$.

${ }^{*} A$ total of eight replicates were used per treatment.

gene expression ${ }^{(16)}$. Heim et al. ${ }^{(16)}$ showed that changes in the expression of intestinal GLUT are directly related to GE digestibility. Similarly, changes in crude protein digestibility have been shown to be accompanied by changes in the gene expression of amino acid and peptide transporters ${ }^{(35)}$. Therefore, in the present study, we aimed to investigate whether dietary PHY inclusion increases the expression of glucose, galactose, fructose, amino acid, peptide, fatty acid, vitamin and mineral transporters. Although not significant, the PHY diet was found to numerically increase ileal $\mathrm{N}$ digestibility compared with the LP diet in the present study. The ileal mRNA expression of PEPT1 was increased in pigs fed the PHY diet compared with that in pigs fed the HP diet. PEPT1 is a major transporter involved in the absorption of the products of protein digestion across the intestinal apical membrane. This indicates that the gene expression of this transporter was upregulated in response to the increase in $\mathrm{N}$ availability as the phytate molecule was hydrolysed in situ ${ }^{(36)}$. Although PHY supplementation increased the gene expression of PEPT1, no effect was observed on the gene expression of the apical membrane amino acid transporters (SLC1A4, SLC6A19 and $S L C 7 A 1$ ) or the basolateral transporters ( $S L C 7 A 11$ and $S L C 1 A 2)$. This indicates that the increased $\mathrm{N}$ availability observed in the present study could be partially influenced by the increased gene expression of PEPT1 ${ }^{(37)}$. This is in agreement with the findings of previous studies where increases in crude protein digestibility were found to be accompanied by changes in PEPT1 expression ${ }^{(35)}$. The HP diet increased the jejunal gene expression of the apical membrane transporter SLC7A1 compared with the LP diet and increased the jejunal gene expression of SLC7A11 compared with the PHY diet.

The HP diet up-regulated the gene expression of SGLT1 compared with the LP diet. The intestinal GLUT SGLT1 is the major transporter involved in the absorption of glucose and other sugars across the luminal membrane of porcine enterocytes $^{(38)}$. The high levels of $\mathrm{Ca}$ and $\mathrm{P}$ present in the inorganic $\mathrm{P}$ supplement may inhibit the ability of the phytate molecule to bind to free glucose, as observed when feeding the LP diet, causing an increased gene expression of $S G L T 1^{(39)}$. In a previous experiment, pigs supplemented with phytic acid have been found to exhibit a reduced expression of $S G L T 1^{(40)}$. This indicates that phytate chelates free glucose and makes it unavailable for digestion, which in turn causes the low expression observed when feeding the LP diet. Following the increased gene expression of the apical membrane transporter SGLT1, an increase in the gene expression of GLUT2, which is expressed on the basolateral membrane of intestinal enterocytes, is to be expected $^{(38)}$. The gene expression of GLUT2 was up-regulated in pigs fed the HP diet when compared with that in pigs fed the LP diet. SGLT1 and GLUT2 together are effectively responsible for glucose absorption ${ }^{(41)}$. The increased gene expression of GLUT2 indicates increased glucose availability from the HP diet, possibly due to the inhibition of the ability of the phytate molecule to bind to free glucose by the inorganic P supplement.

Table 7. Effect of phosphorus and phytase (PHY) levels on the normalised relative abundance of nutrient transporter mRNA in the ileal tissue of weaned pigs

(Least-squares means with their standard errors)

\begin{tabular}{llllll}
\hline Dietary treatments & HP & LP & PHY & SEM & $P$ \\
\hline Glucose & & & & & \\
GLUT2 & $1.26^{\mathrm{a}}$ & $0.26^{\mathrm{b}}$ & $0.94^{\mathrm{a}, \mathrm{b}}$ & 0.29 & 0.032 \\
GLUT5 & 1.31 & 0.62 & 1.09 & 0.30 & 0.315 \\
GLUT7 & 1.46 & 0.71 & 0.94 & 0.37 & 0.362 \\
GLUT8 & 1.02 & 1.01 & 0.99 & 0.10 & 0.973 \\
SGLT1 & $1.32^{\mathrm{a}}$ & $0.51^{\mathrm{b}}$ & $0.79^{\mathrm{a}, \mathrm{b}}$ & 0.31 & 0.022 \\
Protein & & & & & \\
PEPT1 & $1.09^{\mathrm{a}, \mathrm{b}}$ & $0.47^{\mathrm{b}}$ & $1.40^{\mathrm{a}}$ & 0.29 & 0.045 \\
SLC1A4 & 1.10 & 1.41 & 1.04 & 0.14 & 0.146 \\
SLC6A19 & 1.20 & 0.61 & 0.99 & 0.30 & 0.383 \\
SLC7A1 & 1.07 & 1.26 & 1.01 & 0.13 & 0.362 \\
SLC7A11 & 1.12 & 1.10 & 1.07 & 0.18 & 0.976 \\
Fatty acids and vitamins & & & & & \\
CD36 & 1.11 & 1.31 & 1.93 & 0.51 & 0.487 \\
FABP2 & 1.06 & 0.73 & 1.67 & 0.37 & 0.091 \\
VDR & 1.22 & 0.96 & 1.18 & 0.28 & 0.794 \\
Minerals & & & & & \\
TRPV6 & $1.05^{\mathrm{b}}$ & $2.71^{\mathrm{a}}$ & $0.84^{\mathrm{b}}$ & 0.33 & 0.002 \\
PMCA1 & $1.01^{\mathrm{a}}$ & $1.21^{\mathrm{b}}$ & $1.09^{\mathrm{a}, \mathrm{b}}$ & 0.08 & 0.076 \\
Calbindin & $1.63^{\mathrm{b}}$ & $25.03^{\mathrm{a}}$ & $2.78^{\mathrm{b}}$ & 0.37 & 0.004 \\
SLC4OA1 & 1.63 & 0.71 & 0.73 & 0.16 & 0.233 \\
SLC17A4 & 1.24 & 1.47 & 1.33 & 0.32 & 0.823 \\
SLC34A2 & 1.17 & 1.09 & 1.44 & 0.32 & 0.723 \\
\hline
\end{tabular}

$\mathrm{HP}$, high $\mathrm{P}$; LP, low P; SGLT1, sodium-glucose-linked transporter 1; PEPT1, peptide transporter $1 ; C D 36$, cluster of differentiation 36 ; FABP2, fatty acid-binding protein 2; VDR, vitamin D receptor; TRPV6, membrane Ca channel; PMCA1, plasma membrane $\mathrm{Ca}^{2+}$ ATPase.

${ }^{\mathrm{a}, \mathrm{b}}$ Least-squares mean values within a row with unlike superscript letters were significantly different $(P<0.05)$.

${ }^{*}$ A total of eight replicates were used per treatment. 
Similar to that observed for $\mathrm{N}$ digestibility, PHY supplementation was found to increase the CAID of GE in the present study. However, PHY supplementation had no effect on the gene expression of the studied GLUT. The increase in the gene expression of $F A B P 2$ indicates that $\mathrm{PHY}$ was effective at reducing the ability of the phytate molecule to bind to free fat and make it unavailable and could in part explain the increase in the CAID of GE. The fact that PHY has the ability to increase the availability of fat $^{(8)}$ and up-regulate the expression of the fatty acid transporter $F A B P 2$, as observed in the present study, indicates a role for it in increasing the availability of fat. FABP found in the brush border membranes of enterocytes may play a role in fatty acid uptake $^{(42)}$. In a recent study in broilers, PHY supplementation has been found to improve the ileal digestibility of fat along with that of the fat constituents, SCFA and unsaturated fatty acids $^{(42)}$. The formation of mineral-phytate complexes has been reported to prevent the utilisation of lipids. PHY supplementation may increase fat digestibility by reducing the formation of soaps in the gut ${ }^{(43)}$.

$\mathrm{Ca}$ is a mineral that is known to be chelated by the phytate molecule ${ }^{(44)}$. During period 1, the PHY diet was found to improve the CATTD of Ca by 27 and 29\% compared with the LP and HP diets, respectively. Similarly during period 2, the PHY diet was found to improve the CATTD of Ca by 31 and $28 \%$ compared with the LP and HP diets, respectively. Due to low levels of $\mathrm{Ca}$ and $\mathrm{P}$ in the LP diet used in the present study, pigs fed the LP diet exhibited reduced growth and bone mineralisation. PHY supplementation ameliorated the negative effects of the LP diet. The mineral transporters TRPV6, calbindin and PMCA1 were studied as these three $\mathrm{Ca}$ transporters are involved in transcellular $\mathrm{Ca}$ transport (uptake, intracellular movement, and extrusion) ${ }^{(45)}$. A numerical increase was observed in the gene expression of the basolateral $\mathrm{Ca}$ transporter PMCA1 in the jejunum of pigs fed the PHY diet when compared with that in pigs fed the HP diet. These results indicate that the trend of an increased gene expression of TRPVG could partially explain the increased digestibility of $\mathrm{Ca}$ observed in the present study. The gene expression of the $\mathrm{Ca}$ channel TRPVG was increased in the ileum of pigs fed the LP diet when compared with that in pigs fed the other two diets. Similarly, an increased expression of calbindin was observed in pigs fed the LP diet, and a significant trend towards an increased gene expression of the basolateral $\mathrm{Ca}$ transporter PMCA1 was also observed when comparing pigs fed the LP diet with those fed the HP and PHY diets. These results are in agreement with the results of the study carried out by $\mathrm{Li}^{(46)}$, where low levels of $\mathrm{Ca}$ were found to up-regulate the expression of calbindin in broilers. It has previously been established that low levels of dietary Ca can lead to an increased expression of PMCA1 and calbindin in the kidney of mice ${ }^{(45)}$. These results indicate that animals deficient in Ca respond by up-regulating the expression of $\mathrm{Ca}$ transporters to maximise the utilisation of available $\mathrm{Ca}$ in their ileum. In previous experiments ${ }^{(39)}$, it has been shown that the degradation of the phytate molecule predominantly occurs in the stomach and proximal small intestine. This mechanism could explain why the studied Ca transporters were differentially expressed in the ileum and pigs fed the HP and PHY diets exhibited a lower expression.
The majority of Ca absorption in pigs fed the HP and PHY diets will take place in the proximal region of the small intestine due to the easy absorption of $\mathrm{Ca}$ from the inorganic source and the increased availability of Ca following the degradation of the phytate molecule. This is supported by the trend towards an increased expression of TRPVG in the jejunum.

Similar to that observed for Ca digestibility, the PHY diet was found to improve the CATTD of $\mathrm{P}$ by 33 and $22 \%$ compared with the LP and HP diets during period 1, respectively. During period 2, the PHY diet was found to improve the CATTD of $\mathrm{P}$ by 33 and $17 \%$ compared with the LP and HP diets, respectively. The PHY diet improved ileal P digestibility by $25 \%$ compared with the LP diet. A trend towards an increased gene expression of the transporter SLC34A2 was observed in the jejunum of pigs fed the PHY diet compared with the expression in those fed the HP diet. This increased gene expression could partially explain the increased $\mathrm{P}$ digestibility observed in the present study. In the present study, these transporters were not found to be differentially expressed in the ileum. The majority of $\mathrm{P}$ absorption in pigs occurs through the transcellular route and some $\mathrm{P}$ is transported by intestinal transporters ${ }^{(47)}$. The majority of P present in both HP and PHY diets will be released and absorbed in the proximal region of the intestine.

In summary, the PHY diet improved growth performance and bone mineralisation when compared with the HP diet and improved the ileal digestibility of GE and total tract nutrient digestibility of $\mathrm{Ca}$ and $\mathrm{P}$ when compared with the LP diet. The PHY diet improved the gene expression of the peptide transporter PEPT1, the Ca transporter TRPVG, the P transporter $S L C 34 A 2$ and the fatty acid transporter FABP 2 compared with the LP diet. The increase in the gene expression of these nutrient transporters indicates that intestinal nutrient transporter gene expression is a mechanism involved in the uptake of nutrients following the degradation of the phytate molecule.

\section{Acknowledgements}

The authors thank Ms Bernie Flynn, Mr Paddy Reilly, Mr James Callan and Ms Denise Cunningham for their technical assistance.

The present study was funded under the Earth and Natural Sciences Doctoral Studies Programme, which is funded under the Programme for Research in Third-Level Institutions and co-funded under the European Regional Development Fund.

The authors' contributions are as follows: S. V., T. S., C. J. O., J. A. B. and J. V. O. contributed to the conception and design of the study and the analysis and interpretation of the data; S. V. and J. V. O. wrote and edited the article.

None of the authors has any conflicts of interest to declare.

\section{References}

1. Viveros A, Centeno C, Brenes A, et al. (2000) Phytase and acid phosphatase activities in plant feedstuffs. J Agric Food Chem 48, 4009-4013.

2. Noureddini H \& Dang J (2009) Degradation of phytates in distillers grains and corn gluten feed by Aspergillus niger phytase. Appl Biochem Biotechnol 159, 11-23. 
3. Varley PF, Callan JJ \& O'Doherty JV (2010) Effect of phosphorus level and phytase inclusion on the performance, bone mineral concentration, apparent nutrient digestibility, and on mineral and nitrogen utilisation in finisher pigs. Irish J Agric Res 49, 141-152.

4. Harper AF, Kornegay ET \& Schell TC (1997) Phytase supplementation of low-phosphorus growing-finishing pig diets improves performance, phosphorus digestibility, bone mineralization and reduces phosphorus excretion. J Anim Sci 75, 3174-3186.

5. Selle PH, Cowieson AJ, Cowieson NP, et al. (2012) Proteinphytate interactions in pig and poultry nutrition: a reappraisal. Nutr Res Rev 25, 1-17.

6. Johnston SL, Williams SB, Southern LL, et al. (2004) Effect of phytase addition and dietary calcium and phosphorus levels on plasma metabolites and ileal and total-tract nutrient digestibility in pigs. J Anim Sci 82, 705-714.

7. Bikker P, van Diepen JT, Binnendijk GP, et al. (2012) Phytase inclusion in pig diets improves zinc status but its effect on copper availability is inconsistent. J Anim Sci 90, 197-199.

8. Selle PH, Ravindran V, Ravindran G, et al. (2003) Influence of phytase and xylanase supplementation on growth performance and nutrient utilisation of broilers offered wheatbased diets. Asian Austral J Anim 16, 394-402.

9. Lei XG, Ku PK, Miller ER, et al. (1993) Supplemental microbial phytase improves bioavailability of dietary zinc to weanling pigs. J Nutr 123, 1117-1123.

10. Dyer J, Vayro S \& Shirazi-Beechey SP (2003) Mechanism of glucose sensing in the small intestine. Biochem Soc Trans 31, 1140-1142.

11. Dyer J, Salmon KS, Zibrik L, et al. (2005) Expression of sweet taste receptors of the T1R family in the intestinal tract and enteroendocrine cells. Biochem Soc Trans 33, 302-305.

12. Dyer J, Al-Rammahi M, Waterfall L, et al. (2009) Adaptive response of equine intestinal $\mathrm{Na}^{+}$/glucose co-transporter (SGLT1) to an increase in dietary soluble carbohydrate. Eur J Physiol 458, 419-430.

13. Varley PF, Sweeney T, Ryan MT, et al. (2011) The effect of phosphorus restriction during the weaner-grower phase on compensatory growth, serum osteocalcin and bone mineralization in gilts. Livest Sci 135, 282-288.

14. NRC (2012) Nutrient Requirements of Swine, 10th ed. pp. 111-141. Washington, DC: National Academy Press. (20418).

15. McCarthy JF, Bowland JP \& Aherne FX (1977) Influence of method upon the determination of apparent digestibility in the pig. Can J Anim Sci 57, 131-135.

16. Heim G, Walsh AM, Sweeney T, et al. (2014) Effect of seaweed-derived laminarin and fucoidan and zinc oxide on gut morphology, nutrient transporters, nutrient digestibility, growth performance and selected microbial populations in weaned pigs. Br J Nutr 111, 1577-1585.

17. Sweeney T, Collins CB, Reilly P, et al. (2012) Effect of purified beta-glucans derived from Laminaria digitata, Laminaria byperborea and Saccharomyces cerevisiae on piglet performance, selected bacterial populations, volatile fatty acids and pro-inflammatory cytokines in the gastrointestinal tract of pigs. Br J Nutr 108, 1226-1234.

18. AOAC (1995) Official Methods of Analysis, 16th ed. Washington, DC: AOAC.

19. Ramakrishna TV \& Robinson JW (1968) The determination of calcium and magnesium in acetylene flames. Anal Chim Acta 40, 347-350.

20. Cavell AJ (1955) The spectrophotometric determination of phosphorus in plant material. J Sci Food Agric 6, 479-480.
21. O'Shea CJ, McAlpine P, Sweeney T, et al. (2014) Effect of the interaction of seaweed extracts containing laminarin and fucoidan with zinc oxide on the growth performance, digestibility and faecal characteristics of growing piglets. $\mathrm{Br}$ J Nutr 111, 798-807.

22. Van Soest PJ, Robertson JB \& Lewis BA (1991) Methods for dietary fibre, neutral detergent fibre and non starch polysaccharides in relation to animal nutrition. J Dairy Sci $\mathbf{7 4}$, 3583-3597.

23. McCarthy J, Aherne F \& Okai D (1974) Use of 4N HCl insoluble ash as an index material for determining apparent digestibility with pigs. Can J Anim Sci 54, 107-109.

24. Brady SM, Callan JJ, Cowan D, et al. (2003) Effect of two microbial phytases on the performance and nutrient retention on grower-finisher pigs fed barley-maize-soyabean meal-based diets. Irish J Agric Res 42, 101-117.

25. Engelen AJ, van der Heeft FC, Randsdorp PH, et al. (2001) Determination of phytase activity in feed by a colorimetric enzymatic method: collaborative interlaboratory study. J AOAC Int 84, 629-633.

26. Giancoli DC, Corey P and Mullaney R (editors) (1998) Physics, Buoyancy and Archimedes Principle. pp. 282-285. Upper Saddle River: Prentice Hall.

27. Hellemans J, Mortier G, De Paepe A, et al. (2007) qBase relative quantification framework and software for management and automated analysis of real-time quantitative PCR data. Genome Biol 8, R19.

28. Statistical Analysis Systems Institute (1985) Statistical Analysis Systems, Version 6.12. Cary, NC: SAS Institute, Inc.

29. Lei XG \& Stahl CH (2000) Nutritional benefits of phytase and dietary determinants of its efficacy. J Appl Anim Res 17, 97-112.

30. Vats P, Bhattacharyya MS \& Banerjee UC (2005) Use of phytases (myo-inositolhexakisphosphate phosphohydrolases) for combatting environmental pollution: a biological approach. Crit Rev Environ Sci Technol 35, 469-486.

31. Woyengo TA, Sands JS, Guenter W, et al. (2008) Nutrient digestibility and performance responses of growing pigs fed phytase- and xylanase-supplemented wheat-based diets. J Anim Sci 86, 848-857.

32. Varley PF, Flynn B, Callan JJ, et al. (2011) Effect of phytase level in a low phosphorus diet on performance and bone development in weaner pigs and the subsequent effect on finisher pig bone development. Livest Sci 138, 152-158.

33. Selle PH \& Ravindran V (2007) Microbial phytase in poultry nutrition. Anim Feed Sci Technol 135, 1-41.

34. Selle PH, Ravindran V, Ravindran G, et al. (2007) Effects of dietary lysine and microbial phytase on growth performance and nutrient utilisation of broiler chickens. Asian Austral J Anim 20, 1100-1107.

35. Wang X, Zeng P, Feng Y, et al. (2012) Effects of dietary lysine levels on apparent nutrient digestibility and cationic amino acid transporter mRNA abundance in the small intestine of finishing pigs, Sus scrofa. Anim Sci J 83, 148-155.

36. Fei YJ (1994) Expression cloning of a mammalian protoncoupled oligopeptide transporter. Nature 368, 563-566.

37. Gilbert ER, Wong EA \& Webb KE (2008) Board-invited review: peptide absorption and utilization: implications for animal nutrition and health. J Anim Sci 86, 2135-2155.

38. Moran AW, Al-Rammahi MA, Arora DK, et al. (2010) Expression of $\mathrm{Na}^{+} /$glucose co-transporter 1 (SGLT1) in the intestine of piglets weaned to different concentrations of dietary carbohydrate. Br J Nutr 104, 647-655.

39. Yoon JH, Thompson LU \& Jenkins DJ (1983) The effect of phytic acid on in vitro rate of starch digestibility and blood glucose response. Am J Clin Nutr 38, 835-842. 
40. Woyengo TA, Rodriguez-Lecompte JC, Adeola $\mathrm{O}$, et al. (2011) Histomorphology and small intestinal sodiumdependent glucose transporter 1 gene expression in piglets fed phytic acid and phytase-supplemented diets. J Anim Sci 89, 2485-2490.

41. Kellett GL \& Brot-Laroche E (2005) Apical GLUT2: a major pathway of intestinal sugar absorption. Diabetes $\mathbf{5 4}$, 3056-3062.

42. Zaefarian F, Romero LF \& Ravindran V (2013) Influence of a microbial phytase on the performance and the utilisation of energy, crude protein and fatty acids of young broilers fed on phosphorus adequate maize and wheat based diets. $\mathrm{Br}$ Poult Sci 54, 653-660.

43. Ravindran V, Selle PH, Ravindran G, et al. (2001) Microbial phytase improves performance, apparent metabolizable energy, and ileal amino acid digestibility of broilers fed a lysine-deficient diet. Poult Sci 80, 338-344.
44. Graf E (1983) Calcium binding to phytic acid. J Agric Food Chem 31, 851-855.

45. Song Y, Peng X, Porta A, et al. (2003) Calcium transporter 1 and epithelial calcium channel messenger ribonucleic acid are differentially regulated by 1,25 dihydroxyvitamin D3 in the intestine and kidney of mice. Endocrinology 144, 3885-3894.

46. Li J (2012) The influence of dietary calcium and phosphorus imbalance on intestinal NaPi-IIb and calbindin mRNA expression and tibia parameters of broilers. Asian Austral J Anim 25, 552-558.

47. Fan MZ, Shen Y, Yin YL, et al. (2008) Methodological considerations for measuring phosphorus utilization in pigs. pp. 370-397. In Mathematical Modelling in Animal Nutrition. Wallingford: CAB International.

48. Sauvant D, Perez JM and Tran G (editors) (2004) Table of Composition and Nutritional Value of Feed Materials. Pigs, Poultry, Cattle, Sheep, Goats, Rabbits, Horses, Fish. Wageningen: Wageningen Academic Publishers. 